Chem. Ind., 1888, 7, 42 ; abs. Chem. Ztg., Rep., I887, II, 274; abs. $J$. Anal. Chem., I888, 2, III ; abs. Chem. Centrbl., r888, I473; abs. Dingler, I888, 269, 43 .

Traube, J.: Ueber die Untersuchung des Sprits und der spirituösen Getränke, insbesondere über das Vaporimeter im Dienste der Spritanalyse und Spritindustrie. Ztschr. anal. Chem., I889, 28, 26-45; abs. J. Chem. Soc., r889, 56, 654; abs. Chem. Ztg,, Rep., 1889, х3, 27; abs. Ztschr. Chem. Nahr., 1891, 6, 372; abs. Dingler, I891, 281, I17; abs. Chem. Centrbl., $1889, \mathrm{I}, 236-7$.

Traube, J. : Zur Bestimmung von Fuselöl im Spiritus. Chem. Ztg., I89o, I4, I410; abs. J. Chem. Soc., 1892, 62, 543; abs. Chem. Centrbl., I $89 \mathrm{I}$, II, 859 .

Udránszky: Ueber den Nachweis von Fuselöl in Spirituosen. Ztschr. physiol. Chem., 1888, I3, 260-63; abs. Dingler, 1889, 273, 370-7r; abs. Chem. Centrbl., 1889, I, I68.

Uffelmann: Ueber den Nachweis des Fuselöls in Spirituosen. Arch.f. Hyg., I883, I, 445 ; abs. Rep. anal. Chem., 1884, 4, 187-90.

Uffelmann: Zum Nachweis des Fuselöls in Spirituosen. Arch.f. Hyg., 1886, 4, 229-40; Pharm. Centralhalle, 28, 98 ; abs. Ztschr, anal. Chem., I888, 27, 99; abs. Ztschr. Nahr. Hyg., I89I, 5, 3, 5, and 7; abs. Chem Centrbl., I886, 745; abs. Dingler, I886, 26r, 439-42; abs. Rep. anal. Chem., I886, 6, 596-99; Ztschr.f. Hyg., 1887; abs. Chem. News, 1888, I8, 60 .

Vitali: Di una reagione cromatica dell'alcol amilico e della sua ricorca nell'alcool etilico e nel cloroforme. L'Orosi, 6, 328; abs. Arch. der. Pharm., (3), 2I, 964; abs. Ztschr. anal. Chem., 1884, 23, 426; Analyst, I 884,9 , I96.

Windisch, C.: Ueber Methoden zum Nachweis und zur Bestimmung des Fuselöls in Trinkbranntweinen. Arb. a. d. kais. Ges. Amt., 5, 373-93; Abs. Chem. Centrbl., I889, II, 207; abs., Mon.sci., (Ques.), 1889, $33,55^{2}$.

Windisch, C. : Zur Untersuchung des denaturirten Branntweins. Arb. a. d. kais. Ges. Amt., 6, 47I; abs. Dingler, I891, 279, 283; abs. Vjschr. Chem. Nahr., I891, 6, 69.

\title{
THE OCCURRENCE OF TITANIUM.
}

By Charles E. WAIT

Received February Ir, 1896 .

I $T$ is not my present purpose to repeat what has been already frequently published relative to the presence of titanium in minerals, typical rocks, meteorites, clays, soils, blast furnace products, etc. I wish merely to call attention to the fact that some of the bodies with which we have much to do contain titanium, and that probably owing to the difficulties formerly 
experienced in its estimation, it has been more frequently overlooked than is generally supposed.

In the recent examination of food materials, under the direction of the United States Department of Agriculture, I have had occasion to make analyses of the ashes of some plant materials, and this having led to further investigations, I was interested and surprised to find titanium present in every plant ash thus far examined.

This is in fact surprising, as it is stated by some writers ${ }^{1}$ that "it does not appear to form part of the animal or vegetable kingdom."

The amount of titanic oxide found in the ash of some vegetable material is as follows :

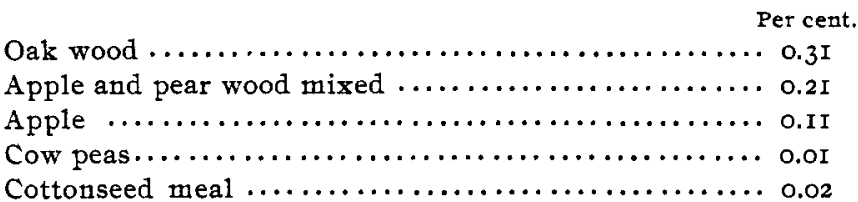

From the above determinations we are reasonably safe in assuming that titanium is assimilated by plants. If this is true, it seems very strange that reference to this fact has not been made by recent writers upon agricultural chemical analysis, and upon the chemistry of vegetable life.

In fact, in consulting treatises on ash analysis with tables, ${ }^{2}$ I do not find any mention whatever of the presence of titanium. If this is a fact, can it be true that it has escaped the attention of chemists for so long a time?

The examination of the ash of bituminous and anthracite coal shows the presence of titanic oxide. The results of some determinations are as follows:

\footnotetext{
Per cent.

Jellico (Tenn.) bituminous coal................ 0.69

Coal Creek (Tenn.) bituminous coal .............. 0.95

Pocahontas (Va.) bituminous coal ............... 0.94

Middlesborough ( $\mathrm{Ky}$. ) bituminous coal............ $0.8_{3}$

Penusylvania anthracite coal $\ldots \ldots \ldots \ldots \ldots \ldots \ldots \ldots \ldots . . \ldots \ldots$

1 Roscoe \& Schorlemmer,
}

2 Wolff. 
With reference to the presence of titanic oxide in the ash of coal, it may be fairly assumed that partly owing to the infiltration of clay and earthy materials, it would be found there, but is it fair to assume that its presence is wholly accounted for in that way? If mention has been made of the presence of titanium in the ash of coal, it has thus far escaped my attention.

The method employed in the above determination is that of A. Weller,' which is based upon the fact that hydrogen peroxide, when added to a solution of titanium, produces a compound of an intensely yellow color. There are precautions necessary in the execution of this method which have already been pointed out."

It will be my pleasure to report additional notes at an early day concerning the presence of titanium in the vegetable kingdom. Valuable service has been rendered in the above work by Messrs. J. O. LaBach and C. O. Hill.

INIMERSTY' ON 'TENAESSEE.

\section{THE ESTIMATION OF PYRRHOTITE IN PYRITES ORES.}

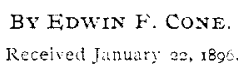

COME of the American pyrites ores contain the mineral pyr$\int$ rhotite $\left(\mathrm{Fe}_{7} \mathrm{~S}_{8}\right)$ in varying proportions. In the manufacture of sulphuric acid from these ores it is found impossible to burn out at least the greater part, if not all, of the sulphur which is present as pyrrhotite. In the estimation of total sulphur in the sample of such an ore, of course the sulphur present as pyrrhotite is included. It is therefore necessary, in order to make a settlement with the company selling the ore and also in order to figure the yield of acid, to estimate the sulphur present as pyrrhotite as accurately as possible. Authorities give no method to meet the conditions. After a careful investigation of the matter I have perfected the following method; I am indebted to Mr. Lucius Pitkin, of New York City, for some valuable suggestions. It is based on the fact that $\mathrm{Fe}_{7} \mathrm{~S}_{8}$ is magnetic, pyrites being non-magnetic.

1 Ber. d. chem. Ges., 1882.

2 This Journal, I3, 210. 